\title{
Apparent digestibility of dried azolla powder incorporated diets in rohu Labeo rohita (Hamilton, 1822)
}

\author{
B. GANGADHAR, H. UMALATHA AND K. HEMAPRASANTH \\ ICAR-Central Institute of Freshwater Aquaculture, Regional Research Centre, Hesaraghatta Lake P. O. \\ Bengaluru - 560 089, Karnataka, India \\ e-mail: gbarlaya@yahoo.co.in
}

\begin{abstract}
Dry matter and nutrient digestibility of dried azolla powder incorporated in the traditional feed was evaluated in advanced fingerlings of Labeo rohita (Hamilton, 1822) reared in aerated indoor plastic tanks. The fish were fed nearly isocaloric diets formulated to contain azolla powder, replacing the main ingredients, groundnut cake and rice bran of the Control diet at 10, 20,30 and $40 \%$ levels. Total dry matter digestibility and major nutrient digestibility were estimated using acid insoluble ash as the marker. Digestibility (\%) of dry matter, protein, fat and nitrogen free extract (NFE) showed a declining trend with increased azolla incorporation. Only protein and fat digestibility of $20 \%$ azolla diet was comparable with that of the Control, with higher incorporation levels resulting in significant reduction in the digestibility values.
\end{abstract}

Keywords: Alternate protein source, Feed ingredient, Fish feed, Rohu

The small leafed floating aquatic plants Azolla spp. are distributed all over the world in freshwater ecosystems of temperate and tropical regions (Kannaiyan and Kumar, 2006) and can be grown easily with minimal expenditure. These aquatic plants with high biomass and protein levels can be used as feed ingredient owing to higher crude protein ( 24 to $30 \%$ on dry weight basis) and essential amino acid content than the majority of green forage crops and other aquatic macrophytes (Panigrahi et al., 2014). Azolla is known to contain other constituents such as minerals, chlorophyll, carotenoids, vitamins (Umalatha et al., 2018) and some probiotics and biopolymers (Pillai et al., 2002). There are studies on the use of azolla in the culture of catla (Asadujjaman and Hosain, 2016), rohu (Mohanty and Dash, 1995; Maity and Patra, 2008; Datta, 2011; Panigrahi et al., 2014; Kumari et al., 2017), fimbriatus (Gangadhar et al., 2015), silver barb (Das et al., 2004), tilapia (Micha et al., 1988; Sithara and Kamalaveni, 2008; Youssouf, 2012) and black tiger shrimp (Sudaaryano, 2006). Results of these studies, however, are mostly inconsistent and ambiguous. Dietary azolla supplementation in most cases seems to be beneficial in terms of growth performance of fish and often resulted in reduced feed cost. Considering its ease of cultivation, higher productivity and nutritive value and the increasing interest in ecologically sound integrated farming systems, it is worth exploring the potential of azolla as an ingredient for fish feed.

The feed cost constitutes a major portion of the production cost in aquaculture practices irrespective of whether it is intensive or semi-intensive. A judicious choice of dietary constituents leading to reduced feed cost is the key to profitable fish farming. Several dietary formulations suiting to the feeding habit of herbivorous aquatic species are commercially available. The conventional carp feed is a mixture of rice bran and groundnut cake in equal proportions. The cost of a kilo of groundnut cake varies from ₹30-50/- depending on quality, while that of rice bran ranges from ₹20-25/- per $\mathrm{kg}$. High cost of these feed ingredients leads to increased expenditure on fish production, which in turn reduces the profit margins in aqua-farming. Therefore, the main criterion for commercial fish farming is the availability of appropriate cost effective feed, formulated from locally obtainable ingredients which are able to fulfill the nutritional requirements of the cultured species. The present study was conducted considering this urgent need for alternate, locally available feed ingredients and in view of the limited availability of literature on the use of azolla as a dietary ingredient for the Indian major carps. Digestibility of ingredients being the key to the use of any feed ingredient, this study evaluated the effect of incorporating varied levels of dried azolla (Azolla microphylla) powder in the conventional feed of one of the important Indian major carps, rohu Labeo rohita (Hamilton, 1822), on the digestibility of dry matter and major nutrients.

The basal diet (Control) was formulated with groundnut oilcake and rice bran (Table 1). Finger millet (ragi) was used at $9 \%$ level as the binder. A. microphylla 
Table 1. Ingredient proportion (\%) and proximate composition ( $\%, \mathrm{Mean} \pm \mathrm{SD})$ of experimental diets

\begin{tabular}{llllll}
\hline Ingredients & Control & $10 \%$ Azolla & $20 \%$ Azolla & $30 \%$ Azolla & $40 \%$ Azolla \\
\hline Groundnut cake & 45 & 40 & 35 & 30 & 25 \\
Rice bran & 45 & 40 & 35 & 30 & 25 \\
Ragi (Finger millet) & 9 & 9 & 9 & 9 & 9 \\
Azolla powder & 0 & 10 & 20 & 30 & 40 \\
Vitamin and mineral mixture* & 1 & 1 & 1 & 1 & 1 \\
\hline Proximate composition & & & & & \\
\hline Moisture & $5.79 \pm 0.08$ & $5.60 \pm 0.07$ & $4.87 \pm 0.10$ & $4.53 \pm 0.06$ & $4.60 \pm 0.06$ \\
Crude protein & $26.02 \pm 0.31$ & $25.98 \pm 0.43$ & $25.55 \pm 0.25$ & $24.96 \pm 0.32$ & $24.85 \pm 0.68$ \\
Fat & $8.26 \pm 0.43$ & $8.04 \pm 0.07$ & $7.86 \pm 0.10$ & $7.62 \pm 0.06$ & $7.33 \pm 0.06$ \\
Ash & $9.81 \pm 0.02$ & $9.88 \pm 0.07$ & $8.69 \pm 0.02$ & $8.40 \pm 0.14$ & $8.24 \pm 0.11$ \\
Crude fiber & $7.81 \pm 0.02$ & $7.88 \pm 0.30$ & $6.69 \pm 1.11$ & $6.41 \pm 0.31$ & $6.24 \pm 0.85$ \\
NFE & $42.12 \pm 1.51$ & $41.99 \pm 0.69$ & $42.80 \pm 0.89$ & $42.36 \pm 1.83$ & $42.43 \pm 2.21$ \\
Gross energy (kJ g & 16.34 & 16.22 & 16.19 & 15.89 & 15.77 \\
\hline
\end{tabular}

*Each kg has Calcium-25.5\%, Phosphorus-12.75\%, Mangessium-6000 mg, Suphur-0.72\%, Sodium-5.9 mg, Potassium-100 mg, Copper-1200 mg, Cobalt-150 mg, Zinc-9600 mg, Iron-1500 mg, Iodine-325 mg, Selenium-10 mg, Manganese-1500 mg, Vitamin A-700000 IU, Vitamin D3-70000 IU, Vitamin E-250 mg, Nicotinamide-1000 mg, DL-methionine-1929 mg, L-lysine-4400 mg, Lactobacillus $\mathrm{sp} .1 .5 \times 10^{11}$ CFU, Saccharomyces cerevisiae -30000 million CFU.

grown under controlled conditions in circular cement tanks were harvested, sun dried for 3-4 days and powdered at required quantities before feed preparation. Four experimental diets were formulated replacing groundnut oilcake and rice bran in the basal diet with azolla at 10 (10\% Azolla), 20 (20\% Azolla), 30 (30\% Azolla) and $40 \%$ (40\% Azolla) levels as per Umesh et al. (1994). For preparation of feed, groundnut oilcake and finger millet were dried, powdered and all the ingredients were sieved through a $0.5 \mathrm{~mm}$ meshed screen. The ingredients at appropriate quantity were mixed with hot water to make a dough, which was then pressed through a hand pelletiser to get uniform sized pellets $(2 \mathrm{~mm})$. The pellets were dried under sun and packed in air tight bags till use.

Apparent digestibility of the test diets was evaluated in vivo through a feeding experiment carried out in indoor, aerated, plastic tanks of 501 capacity. Ten advanced rohu fingerlings $(8.50-11.00 \mathrm{~g})$ were stocked in 15 aerated tanks and acclimated for ten days with the Control diet. The control and test diets were fed every morning at $1000 \mathrm{hrs}$ to the fish in the designated triplicate tanks till satiation. Fish were allowed to feed for $6 \mathrm{~h}$ and at the end of the feeding period, the unconsumed pellets were siphoned out. On the following day, faecal matter from each experimental tank was collected by filtering through a $15 \mu \mathrm{m}$ meshed nylon cloth. The faecal matter collected was dried and stored for the analysis of proximate composition. About half of water from each tank was replaced with freshwater daily after faecal matter collection. Feeding and faecal matter collection was undertaken for a period of 45 days.

Feed ingredients, pelleted feed and collected faecal material were subjected to proximate analysis (AOAC, 1995). Gross energy content of the diet was calculated following Mayes (1990). Acid insoluble ash was used as the reference marker (Goddard and McLean, 2001; Li et al., 2008; Bob-Manuel, 2013). Dry matter and nutrient digestibility were calculated according to Maynard and Loosli (1972). Water quality parameters viz, dissolved oxygen and total alkalinity were analysed following APHA (2005), while $\mathrm{pH}$ and temperature were recorded using probes (Orion 2 Star $\mathrm{pH}$ meter, Thermo Electron Corporation, USA), at fortnightly intervals.

Data on digestibility were compared employing one-way ANOVA. Further, pair-wise comparison of treatment means was done by Duncan's multiple range test $(\mathrm{p}=0.05)$ (Duncan, 1955).

The average temperature of tank water ranged from 24.98 to $25.22^{\circ} \mathrm{C}$ during the study period. Water showed alkaline conditions with average $\mathrm{pH}$ ranging from 7.34 to 8.10 and total alkalinity from 300.16 to $313.01 \mathrm{mg} \mathrm{l}^{-1}$. Dissolved oxygen levels varied between 5.86 and $7.26 \mathrm{mg} \mathrm{l}^{-1}$ (Table 2 ). The major water quality parameters recorded were within the acceptable limit for the culture of carps (Jena et al., 2011) and no significant ( $\mathrm{p}>0.05)$ difference between the treatments was recorded.

Dutta et al. (2011) reported the chemical composition of A. microphylla from field condition as $20.2 \%$ crude protein, $3.5 \%$ crude fat, $15.8 \%$ crude fibre and $17.2 \%$ ash. Chatterjee et al. (2013) reported $24.1 \%$ crude protein, $3.3 \%$ crude fat, $13.4 \%$ crude fibre and $19.5 \%$ ash in A. microphylla produced in the experimental production unit. The proximate composition values obtained in the present study were close to those reported earlier, being $25.5 \%$ crude protein, $7.0 \%$ crude fat, $15.8 \%$ crude fibre and $20 \%$ ash. 
Table 2. Water quality parameters (Mean $\pm \mathrm{SD}$ ) recorded in the experimental tanks during the study period

\begin{tabular}{llllll}
\hline Water quality & Control & $10 \%$ Azolla & $20 \%$ Azolla & $30 \%$ Azolla & $40 \%$ Azolla \\
\hline Temperature $\left({ }^{\circ} \mathrm{C}\right)$ & $25.22 \pm 0.53$ & $25.09 \pm 0.25$ & $25.06 \pm 0.23$ & $24.98 \pm 0.21$ & $25.21 \pm 0.14$ \\
$\mathrm{pH}$ & $8.10 \pm 0.12$ & $7.79 \pm 0.31$ & $7.49 \pm 0.11$ & $8.00 \pm 0.12$ & $7.34 \pm 0.03$ \\
Dissolved oxygen $\left(\mathrm{mg} \mathrm{l}^{-1}\right)$ & $7.00 \pm 1.32$ & $6.67 \pm 1.09$ & $5.86 \pm 1.11$ & $7.26 \pm 0.48$ & $6.87 \pm 1.22$ \\
Total alkalinity $\left(\mathrm{mg} \mathrm{CaCO}_{3} \mathrm{l}^{-1}\right)$ & $308.78 \pm 3.81$ & $307.87 \pm 7.61$ & $313.01 \pm 9.31$ & $311.49 \pm 5.18$ & $300.16 \pm 4.56$ \\
\hline
\end{tabular}

The nutritive value of food depends on the capacity of the animal to digest and absorb the nutrients and the efficiency of digestion of the ingested food largely determines the growth performance of the animal (Deganp and Yehuda, 1999). There was an apparent reducing trend in the digestibility (\%) of dry matter, protein, fat and NFE with increased dietary incorporation levels of azolla. Only protein and fat digestibility of $20 \%$ Azolla diet was comparable with that of the Control, higher incorporation levels showing significant reduction in the digestibility values (Table 3 ). Fish belonging to the family Cyprinidae have been experimentally fed diets with different azolla inclusion levels. In earlier studies also, better feed utilisation and increased growth was recorded in rohu at dietary azolla inclusion levels of $10-50 \%$ (Datta, 2011; Panigrahi et al., 2014). Kumari et al. (2017) recommended $20 \%$ azolla supplementation in the diet of L. rohita, while according to Datta (2011), it can go up to $25 \%$. Maity and Patra (2008) also recommended 25\% level of Azolla pinnata for better growth, food conversion and protein efficiency ratio in rohu. Incorporation of A. pinnata at $10-25 \%$ levels resulted in higher growth of rohu due to the $\omega-6$ fatty acids present in azolla (Mohanty and Dash, 1995). submerged vegetation (Alam et al., 2011), is expected to utilise azolla better compared to other IMCs. The study by Asadujjaman and Hosain (2016) revealed that the growth of catla (Catla catla) fed azolla was inferior to those fed control diet consisting of rice bran, wheat bran and mustard cake (30:30:40). Total dry matter digestibility (DMD) and protein digestibility of azolla diets in catla were comparable with the control diet up to $20 \%$ incorporation $(\mathrm{p}>0.05)$, reducing there after $(\mathrm{p}<0.05)$ (Umalatha et al., 2018). In similar studies conducted with L. fimbriatus and Cyprinus carpio, dry matter and protein digestibility decreased at azolla incorporation levels above 20\% (Gangadhar et al., 2017a) and that with a medium carp Labeo calbasu, total DMD and fat digestibility decreased at levels above 30\% (Gangadhar et al., 2017b). Silver carp and mrigal (Tuladhar, 2003), grass carp (Majhi et al., 2006) and Thai silver barb (Das et al., 2018) were also reported to have azolla inclusion levels in the range between $10-25 \%$. Incorporation of more than $25 \%$ azolla in the diet led to reduced food utilisation in Etroplus suratensis (Joseph et al., 1994). Reduction in the digestibility can be attributed to increasing crude fibre content, including lignin level, resulting in swift movement of food through the gut of the

Table 3. Digestibility (\%) of dry matter, protein, fat and NFE by rohu in the experimental diets

\begin{tabular}{lllll}
\hline Diets & Dry matter digestibility & Protein digestibility & Fat digestibility & NFE digestibility \\
\hline Control & $81.70 \pm 0.62^{\mathrm{c}}$ & $87.97 \pm 0.40^{\mathrm{c}}$ & $99.39 \pm 0.12^{\mathrm{c}}$ & $91.33 \pm 0.95^{\mathrm{c}}$ \\
$10 \%$ Azolla & $76.92 \pm 1.24^{\mathrm{b}}$ & $85.72 \pm 0.47^{\mathrm{c}}$ & $99.48 \pm 0.03^{\mathrm{c}}$ & $83.13 \pm 1.26^{\mathrm{b}}$ \\
$20 \%$ Azolla & $76.00 \pm 1.66^{\mathrm{b}}$ & $85.17 \pm 0.74^{\mathrm{c}}$ & $96.76 \pm 0.79^{\mathrm{c}}$ & $84.22 \pm 0.94^{\mathrm{b}}$ \\
$30 \%$ Azolla & $65.42 \pm 2.45^{\mathrm{a}}$ & $77.59 \pm 1.43^{\mathrm{b}}$ & $93.60 \pm 1.02^{\mathrm{b}}$ & $80.46 \pm 1.63^{\mathrm{ab}}$ \\
$40 \%$ Azolla & $64.96 \pm 0.66^{\mathrm{a}}$ & $73.45 \pm 1.68^{\mathrm{a}}$ & $93.61 \pm 0.65^{\mathrm{a}}$ & $77.22 \pm 1.30^{\mathrm{a}}$ \\
\hline
\end{tabular}

Figures in the same column with same superscript do not differ significantly $(\mathrm{p}>0.05)$.

Sheeno and Sahu (2006) observed that azolla protein concentrate is a good source of protein and can be used to the maximum extent of $16.25 \%$ in the diet of $L$. rohita. The same authors also recorded lower protein and carbohydrate digestibility in rohu fed azolla protein concentrate in the diet above 24 and $16 \%$ levels respectively.

Species specific differences in nutrient and energy digestibility of various feed ingredients have been observed mainly due to the differences in the feeding habits of fish (Refstie et al., 2000). Rohu, being a herbivorous fish consuming mainly phytoplankton and animal, thereby lessening the time available for digestion and absorption of the diet (Ayyappan, 2000).

Based on the results of the present study, it is concluded that dietary incorporation of dried azolla up to $20 \%$ level does not affect nutrient digestibility in L. rohita. The results of this study add to the knowledge on utilisation of azolla in the diet of $L$. rohita.

\section{Acknowledgements}

The authors are grateful to the Director, ICAR-CIFA, Bhubaneswar for providing infrastructure facilities for conducting this experiment. 


\section{References}

Alam, M., Sharma, S. and Pathak, J. K. 2011. Food preferences of Labeo rohita (Hamilton) in river Ramganga, Uttar Pradesh, India. Int. J. Fish. Aquac. Sci., 1(2): 99-105.

AOAC 1995. Official methods of analysis, $16^{\text {th }}$ edn, Association of Official Analytical Chemists, Washington DC, USA, p. 32-42.

APHA 2005. Standard methods for the examination of water and wastewater. American Public Health Association, Washington, DC, USA, 1268 pp.

Asadujjaman, M. and Hossain, M. A. 2016. Fish growth, yield and economics of conventional feed and weed based polyculture in ponds. J. Fish., 4: 353-360.

Ayyappan, S. 2000. Microbial technology for aquaculture. In: UNESCO-MIRCEN Training Manual on 'Aquatic microbiology and microbial diseases. 25 April - 1 May, 2000. Central Institute of Freshwater Aquaculture, Bhubaneswar, India, p. 1-16.

Bob-Manuel, F. G. 2013. Methods used in digestibility evaluation of fish diets: A review and challenges. Cont. J. Fish. Aquat. Sci., 7(2): 25-37.

Chatterjee, A. Sharma, P., Ghosh, M. K., Mandal, M. and Roy, P. K. 2013. Utilisation of Azolla microphylla as feed supplement for crossbred cattle. Int. J. Agri. Food Sci. Technol., 4(3): 207-214.

Das, M., Rahim. F. I. and Hossain, M. A. 2018. Evaluation of fresh Azolla pinnata as a low-cost supplemental feed for Thai silver barb Barbonymus gonionotus. Fishes, 3: 1-11. https://doi.org/10.3390/fishes3010015.

Das, P. C., Sinhababu, D. P., Singh, D. P. and Sahu, P. K. 2004. Utilisation of sun-dried Azolla caroliniana in substituting groundnut oil cake in the conventional carp feed. J. Aquac., 12: 43-47.

Datta, S. N. 2011. Culture of azolla and its efficacy in diet of Labeo rohita. Aquaculture, 310(3-4): 376-379. DOI:10.1016/j. aquaculture.2010.11.008.

Deganp, G. and Yehuda, Y. 1999. Digestibility of protein sources in feed for Oreochromis aureus x O. nilotica. Indian $J$. Fish., 46: 33-39.

Duncan, D. B. 1955. Multiple range and multiple F-tests. Biometrics, 11: 1-42. https://doi.org/10.2307/3001478.

Goddard, J. S. and McLean, E. 2001. Acid-insoluble ash as an inert reference material for digestibility studies in tilapia (Oreochromis niloticus). Aquaculture, 194: 93-98. DOI: 10.1016/s0044-8486(00)00499-3.

Gangadhar, B., Sridhar, N., Saurabh, S., Raghavendra, C. H. and Hemaprasanth, K. P. 2015. Effect of azolla-incorporated diets on the growth and survival of Labeo fimbriatus during fry-to fingerling rearing. Cogent Food Agric., 1: 1055539.

Gangadhar, B., Umalatha, H., Saurabh, S. and Sridhar, N. 2017a. Digestibility of dry matter and nutrients from three ingredients by the carps, Labeo fimbriatus (Bloch, 1795) and Cyprinus carpio (Linnaeus, 1758) with a note on digestive enzyme activity. Indian J. Fish., 4(3): 75-84. DOI:10.21077/ijf.2017.64.3.69091-11.

Gangadhar, B., Umalatha, H., Hegde, G. and Sridhar, N. 2017b. Digestibility of dry matter and nutrients from Azolla pinnata by Labeo calbasu (Hamilton, 1822) with a note on digestive enzyme activity. Fish. Technol., 54: 94-99.

Jena, J. K., Das, P. C., Mitra, G., Patro, B., Mohanta, D. and Mishra, B. 2011. Evaluation of growth performance of Labeo fimbriatus (Bloch), Labeo gonius (Hamilton) and Puntius gonionotus (Bleeker) in polyculture with Labeo rohita (Hamilton) during fingerlings rearing at varied densities. Aquaculture, 319: 493-496.

Joseph, A., Sherief, P. M. and James, T. 1994. Effect of different dietary inclusion levels of Azolla pinnata on the growth, food conversion and muscle composition of Etroplus suratensis (Bloch.). J. Aquac. Trop., 9: 87-94.

Kannaiyan, S. and Kumar, K. 2006. Biodiversity of Azolla and its algal symbiont, Anabaena azollae. NBA Scientific Bulletin No. -2, National Biodiversity Authority, Chennai, Tamil Nadu, India, p. 1-31.

Kumari, R., Ojha, M. L., Saini, V. P. and Sharma, S. K. 2017. Effect of Azolla supplementation on growth of rohu (Labeo rohita) fingerlings. J. Entomol. Zool. Stud., 5: 1116-1119.

Li, P., Webb, K. A. and Gatlin, D. M. 2008. Evaluation of acidinsoluble ash as an indicator for digestibility determination with red drum, Sciaenops ocellatus and hybrid striped bass, Morone chrysops X M. saxatilis. J. World Aquac. Soc., 39(1): 120-125.

Maity, J. and Patra, B. C. 2008. Effect of replacement of fishmeal by Azolla leaf meal on growth, food utilisation, pancreatic protease activity and RNA/DNA ratio in the fingerlings of Labeo rohita (Ham.). Can. J. PureAppl. Sci., 2(2): 323-333.

Majhi, S. K., Das, A. and Mandal, B. K. 2006. Growth performance and production of organically cultured grass carp Ctenopharyngodon idella (Val.) under mid-hill conditions of Meghalaya; North Eastern India. Turk. J. Fish. Aquat. Sci., 6: 105-108.

Mayes, P. A. 1990. Nutrition. In: Murray, R. K., Granner, D. K., Mayes, P. A. and Rodwell, V. W. (Eds.), Harper's biochemistry, $22^{\text {nd }}$ edn. Prentice Hall International Inc., USA, p. 571-579.

Maynard, L. A. and Loosli, J. K. 1972. Animal nutrition, $6^{\text {th }}$ edn. McGraw-Hill, New York, USA.

Micha, J. C., Antoine, T., Wery, P. and Van Hove, C. 1988. Growth, ingestion capacity, comparative appetency and biochemical composition of Oreochromis niloticus and Tilapia rendalli fed with Azolla. In: Pullin, R. S. V., Bhukaswan, T., Tonguthai, K. and Maclean, J. L. (Eds.), Proceedings of the Second International Symposium 
on Tilapia in Aquaculture. International Centre for Living Aquatic Resources and Management (Presently WorldFish), Manila, Philippines, p. 343-355.

Mohanty, S. N. and Dash, S. P. 1995. Evaluation of Azolla caroliniana for inclusion in carp diet. J. Aquac. Trop., 10(4): 343-353.

Panigrahi, S., Choudhary, D., Sahoo, J. K., Das, S. S. and Rath, R. K. 2014. Effect of dietary supplementation of Azolla on growth and survivability of Labeo rohita fingerlings. Asian J. Anim. Sci., 9(1): 33- 37.

Pillai, P. K., Premalatha, S. and Rajamony, S. 2002. Azolla - A sustainable feed substitute for livestock. Leisa Magazine India, 3: 15-17.

Refstie, S., Korsøen, O. J., Storebakken, T., Baeverfjord, G., Lein, I. and Roem, A. J. 2000. Differing nutritional responses to dietary soybean meal in rainbow trout (Oncorhynchus mykiss) and Atlantic salmon (Salmo salar). Aquaculture, 190: 49-63. DOI:10.1016/S0044-8486 (00)00382-3.

Sheeno, T. P. and Sahu, N. P. 2006. Use of freshwater aquatic plants as a substitute of fish meal in the diet of Labeo rohita fry. J. Fish. Aquat. Sci., 1(2): 126-135. DOI: 10.3923/ jfas.2006.126.135.
Sithara, K. and Kamalaveni, K. 2008. Formulation of low-cost feed using Azolla as a protein supplement and its influence on feed utilisation in fishes. Current Biota, 2: 212-219.

Sudaaryano, A. 2006. Use of Azolla meal as a substitute for defatted soybean meal in diets of juvenile black tiger shrimp (Penaeus monodon). J. Coast. Dev., 9: 145-154.

Tuladhar, B. 2003. Comparative study of fish yields with plant protein sources and fish meal. Our Nature, 1: 26-29.

Umalatha, H., Gangadhar, B., Hegde, G. and Sridhar, N. 2018. Digestibility of three feed ingredients by Catla catla (Hamilton, 1822). Oceanogr. Fish. Open Access J., 5: 555-672.

Umesh, N. R., Dathathri, K., Nandeesha, M. C., Gangadhar, B. and Varghese, T. J. 1994. Digestibility of dry matter and protein and Spirulina platensis by common carp, Cyprinus carpio, with a note on time of faeces collection in digestibility estimations. In: De Silva, S. S. (Ed.), Fish nutrition research in Asia. Proceedings of the Fifth Asian Fish Nutrition Workshop. Asian Fisheries Society Special Publication 9. Asian Fisheries Society, Manila, Philippines, p. $81-84$

Youssouf, A. 2012. Water quality and sediment features in ponds with Nile tilapia (Oreochromis niloticus L.) fed Azolla. J. Fish. Aquac., 3: 47-51. 